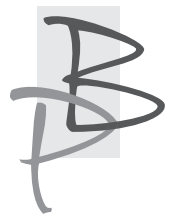

\title{
Halina Turkiewicz*
}

Akademia Edukacji Uniwersytetu Witolda Wielkiego, Wilno

https://orcid.org/0000-0002-4368-7063

\section{Inspiracje Mickiewiczowskie w najnowszej polskojęzycznej poezji Litwy}

Streszczenie: Artykuł analizuje najnowszą polską poezję Litwy, która powstała bądź była wydana w dwóch pierwszych dziesięcioleciach XX wieku, pod kątem obecności w niej motywów Mickiewiczowskich. W toku badań autorka dochodzi do wniosku, że motywy dotyczące biografii bądź twórczości Wieszcza, chociaż nadal są obecne w dorobku autorów wileńskich, jednak nieco się wyciszają. Jest to związane, między innymi, ze zmianą pokoleniową. Niektórzy przedstawiciele starszej generacji poetów odeszli na wieczną wartę. Ich następcy, z kolei, mają obecnie nieco bardziej utrudniony dostęp do położonych na Białorusi miejsc Mickiewiczowskich, które jeszcze niedawno były istotnym źródłem inspiracji. Młodsze pokolenie poetyckie preferuje natomiast bardziej uniwersalną, egzystencjalną problematykę, mniej poważnie traktuje tradycję, w tym Mickiewiczowską, wpisując się w najnowsze trendy literackie.

Słowa-klucze: najnowsza polska poezja Litwy, inspiracje Mickiewiczowskie, tradycja, romantyzm, pokolenie poetyckie.

* Halina Turkiewicz - dr, docent w Akademii Edukacji Uniwersytetu Witolda Wielkiego w Wilnie, historyk literatury polskiej, nauczyciel akademicki; autorka licznych artykułów naukowych głównie z zakresu historii literatury polskiej XX wieku, w tym też literatury polskiej na Litwie, m. in. Litewsko-romantyczne motywy w twórczości Kazimiery Itłakowiczówny (1996), Helena Romer-Ochenkowska jako publicystka „Kuriera Wileńskiego” w latach dwudziestych XX wieku (2000). 


\section{Mickiewicz's inspirations in the latest Polish-language poetry in Lithuania}

Summary: The article analyzes the latest Polish poetry of Lithuania, which was created or published in the first two decades of the $20^{\text {th }}$ century, in terms of the presence of Mickiewicz's motifs. In the course of research, the author comes to the conclusion that the motifs regarding the biography or works of "the national prophet", although they are still present in the works of Vilnius-based authors, however, become less apparent. It is associated, among other things, with the change of generations. Some representatives of the older generation of poets passed away. Their successors, in turn, now have a slightly more difficult access to Mickiewicz-related places in Belarus, which until recently were an important source of inspiration. The younger generation of poets, on the other hand, prefer more universal, existential issues, treat tradition less seriously, including Mickiewicz's, fitting into the latest literary trends.

Key words: latest Polish poetry of Lithuania, Mickiewicz's inspirations, tradition, romanticism, poetic generation.

Prezentowany temat jest kontynuacją refleksji, podjętych w jednym z moich wcześniejszych artykułów, zainspirowanych przez udział w Międzynarodowej Konferencji Naukowej „Wilno i Ziemia Mickiewiczowskiej pamięci”, której inicjatorką była śp. prof. Elżbieta Feliksiak. W roku 1998, roku 200-lecia urodzin Wieszcza, omawiałam Motywy Mickiewiczowskie w twórczości współczesnych poetów wileńskich ${ }^{1}$.

Od tamtego czasu minęło już ponad dwadzieścia lat. Literatura polska na Litwie, zwłaszcza poezja, rozwija się nadal, wchłaniając ,blaski i cienie” no-

$1 \quad$ H. Turkiewicz, Motywy Mickiewiczowskie w twórczości współczesnych poetów wileńskich, [w:] Wilno i Ziemia Mickiewiczowskiej pamięci. Materiaty III Międzynarodowej Konferencji w Białymstoku 9-12 IX 1998 w trzech tomach, t. 2, red. E. Feliksiak i E. Sidoruk, Białystok 2000, s. 291-310. 
wej rzeczywistości, zachowując jednocześnie w jakimś stopniu związek z tradycją romantyczną, w pierwszej kolejności Mickiewiczowską. Powoływanie się poetów na nazwisko czy którykolwiek z utworów Mickiewicza nie jest najczęściej wyrazem głębokiej znajomości dzieł Wieszcza, ogranicza się zazwyczaj do penetrowania repertuaru, utrwalonego przez program szkół polskich na Litwie. Można zatem stwierdzić, że jedną z istotnych inspiracji jest kanon lektur szkolnych, a do takowych należą głównie wybrane ballady, Dziady, Grażyna, Pan Tadeusz oraz poszczególne wiersze, zamieszczane w podręcznikach literatury polskiej dla różnych klas.

Niewysychające do dzisiaj źródło inspiracji to oczywiście również bezpośredni ogląd miejsc i obiektów, naznaczonych niegdysiejszą obecnością poety. Ten motyw zawsze był ważny. Omawiając wiersze poetów wileńskich, powstałe w drugiej połowie XX wieku, poświęciłam mu we wspomnianym artykule bodaj najwięcej miejsca.

Co się zmieniło w ujmowaniu tego tematu w ostatnich dziesięcioleciach, czyli na początku wieku XXI?

Jeżeli w artykule z roku 2000 miałam możliwość przywoływania pokaźnej wiązki tekstów, poświęconych „,małej ojczyźnie” poety, wierszy zainspirowanych pobytem naszych twórców w Zaosiu, nad Świtezią, w Nowogródku, Bolcienikach, Bieniakoniach, to obecnie ograniczyć się należy do utworów wynikłych głównie z chodzenia „wileńskimi śladami Mickiewicza”. Dlaczego tak się dzieje, nietrudno się domyślić. Granica z Białorusią, wytyczona po odzyskaniu przez Litwę niepodległości w 1990 roku, znacznie utrudniła odwiedzanie miejsc związanych z życiem Mickiewicza, położonych na terenie sąsiedniego państwa. Nic zatem dziwnego, że pewne motywy, zwłaszcza „ślady białoruskie", zaczynają się wyciszać.

Inna wielka strata. Na początku XXI wieku milknie na zawsze świetny znawca miejsc Mickiewiczowskich na Białorusi Michał Wołosewicz (19252004), który, mieszkając w Bieniakoniach, gdzie przy miejscowym kościele jest pochowana Maria z Wereszczaków Puttkamerowa, przez długie lata urozmaicał poezję o tematyce Mickiewiczowskiej także o motyw legendarnej miłości Adama i Maryli.

Wracając zatem do poezji ostatnich dziesięcioleci, zatrzymajmy się przy śladach wileńskich, na początek $W$ Świętojańskim kościele $w$ Wilnie. Jest to tytuł wiersza Wojciecha Piotrowicza, zamieszczonego w dwujęzycznym, litewsko- 
polskim zbiorku Spalvos ir digresijos i Barwy / dygresje (Wilno 2002), wydanym we współautorstwie z litewską poetką Oną Zitą Šalnienè. W kościele „uniwersyteckim” mieści się, jak wiadomo, popiersie Mickiewicza, ufundowane przez rodaków z okazji 100-lecia urodzin Wieszcza, które przypadało na rok 1898. Popiersie znajduje się w miejscu, w którym podobno Mickiewicz najczęściej skupiał się na modlitwie. Poeta współczesny, prowadząc dialog ze swoim wielkim poprzednikiem, nawiązuje do tego właśnie faktu, łącząc przeszłość z dzisiejszymi realiami:

\author{
[...] Może dociekasz sensu młodzieńczej modlitwy \\ i rozważasz \\ czy która droga nie jest mylna \\ snując wątek dziejowy nam współczesnej Litwy \\ I tęsknisz do otwartej Europy \\ i Wilna ${ }^{2}$
}

W wierszu Coś z magii tenże Piotrowicz, wskrzeszając sławną przeszłość Wilna, wymieniając poczet związanych z miastem „królów-duchów”, od Kochanowskiego po Miłosza i Konwickiego, nie może, oczywiście, pominąć Mickiewicza. Nawiązuje tym razem w sposób nieco żartobliwy do arcyważnego dla Mickiewicza i literatury faktu, od którego bierze początek romantyzm polski:

\title{
[...] Od Zawadzkiego niesie Adam małą książeczkę ważką za co po wieku jemu stawia czasowy pomnik Pronaszko $[\ldots]^{3}$.
}

Nie jest to typowa dla Piotrowicza poetyka, twórcy preferującego zazwyczaj wiersz biały. Wskrzeszając przeszłość przez stosowanie tak zwanego praesens historicum, poeta nawiązuje do tradycji międzywojennych regionalistów

2 O. Z. S̆alnienė, W. Piotrowicz, Spalvos ir digresijos / Barwy i dygresje, Vilnius 2002, s. 40 .

3 W. Piotrowicz, Coś z magii, [w:] Przenieść Wilno do serca. Portret miasta, zebr. i oprac. R. Mieczkowski, Wilno 2009, s. 108. 
wileńskich (przede wszystkim Wandy Dobaczewskiej, Tadeusza Łopalewskiego, Witolda Hulewicza).

Tradycja regionalna jest bliska zwłaszcza Władysławie OrszewskiejKursevičienė, autorce zbiorku poetyckiego Ścieżka przez życie (Wilno 2010), która uprawia głównie tradycyjny wiersz rymowany, podobnie jak należący do tego samego pokolenia Aleksander Śnieżko. Jej wiersz Stare Wilno zaczyna się od charakterystycznej dla poezji regionalnej konstatacji:

Tak dużo wspaniałych miast

Lecz Wilno jest najpiękniejsze, Jaśniejsze od jasnych gwiazd, Niż zorza poranna piękniejsze [...]

Następnie w podobnym duchu wymieniane są osobliwości architektoniczno-krajobrazowe, po czym przychodzi kolej na przywołanie sfery sacrum z Ostrą Bramą na czele, przypomnienie dostojnych władców, artystów, poetów, wśród których nie może, oczywiście, zabraknąć romantyków, zwłaszcza Mickiewicza:

\author{
[...] Wileński deptali bruk \\ Mickiewicz, Zan i Słowacki, \\ Wspaniały romantyzm ich \\ Zna cały świat literacki. [... $]^{4}$
}

Wskrzeszanie w niewyszukanych wersach pamięci o sławnych przodkach, zanurzanie się w przeszłość pełni, między innymi, funkcję terapeutyczną, pozwala pisać wiersze optymistyczne, nobilitujące przestrzeń, z której wywodzą się współcześni poeci wileńscy, pozwala zapomnieć o „gorszym” dzisiaj.

Nie wszyscy zdradzają skłonność do całkowitego przenoszenia się w przeszłość. Motywy Mickiewiczowskie nie od dzisiaj, jak wiadomo, obecne są w poezji Romualda Mieczkowskiego. Znane są jego wcześniejsze wiersze W podwórzu u Mickiewicza, Podłoga w Celi Konrada i inne.

4 W. Orszewska-Kursevičienè, Ściè̇ka przez życie, Wydawnictwo Polskie w Wilnie 2010, s. 51. 
Nowsze zbiorki poety zawierają kolejne teksty o tej tematyce. Dokonuje się w nich często konfrontacja wielkiego „wczoraj” z miałkim „dzisiaj”. Niepokój poety wzbudza nikłość śladów po wielkich ludziach, nawet tych, którym przypadło w udziale miano wieszczów. W wierszu Sprzedaje się mieszkanie pada, na przykład, stwierdzenie:

$$
\begin{aligned}
& \text { Nie ma ani śladu trwożnego spojrzenia Juliusza w oknie } \\
& \text { wypatrującego czy aby Adam tędy nie przechodzi }[\ldots]^{5} \text {. }
\end{aligned}
$$

Chodzi w tym wypadku o okno domu przy ulicy Zamkowej 22. Popiersie Słowackiego, zaprojektowane przez Ferdynanda Ruszczyca, zostało odsłonięte na budynku przy ulicy Zamkowej (dzisiaj Pilies) w dniu złożenia prochów poety na Wawelu, 28 czerwca 1927 roku.

W 1999 roku na tymże domu odsłonięto tablicę pamiątkową, poświęconą Ruszczycowi - „dar współczesnej Polskiej Ambasady” - jak mówi poeta.

$$
\begin{aligned}
& \text { W oknie kamienicy poety i malarza ogłoszenie - } \\
& \text { Ober Haus nekilnojamasis turtas parduoda butą-patalpą } \\
& \text { Pewnie im wszystko jedno za ile sprzeda ich dawne sny } \\
& \text { firma Ober Haus handlująca nieruchomościami w mieście }
\end{aligned}
$$

Chodzi, oczywiście, o sny Słowackiego i Ruszczyca. Nie lepiej jest z pamięcią o czczonym przez oba narody, polski i litewski, Mickiewiczu. Autentyczna Cela Konrada w byłym klasztorze bazylianów musiała ustąpić miejsce luksusowym apartamentom hotelowym. Mówi o tym wiersz Mieczkowskiego W atrapie Celi Konrada:

$$
\begin{aligned}
& \text { [...] W baraczku - jak go nazwali wilnianie } \\
& \text { urzęduje administracja firmy „U Bazylianów” } \\
& \text { co hotel urządziła w byłym klasztorze } \\
& \text { a sobie nową "Celę Konrada” zbudowała - }
\end{aligned}
$$

\footnotetext{
5 R. Mieczkowski, Nikt nie woła, Wilno 2008, s. 8.

6 Tamże.
} 


\begin{abstract}
w celu pozyskania dodatkowych metrów jako podpory dla swych czterech gwiazdek

Któż by mógł pomyśleć że tablica ze słowami. hic obit est Gustavus - hic natus est Conradus co bez szwanku przetrwała kilka okupacji ze ściany zostanie w biały dzień wyrwana w grodzie Mickiewicza w czasach demokracji [...] $]^{7}$.
\end{abstract}

Nie przetrwała także ulica Mickiewicza, przynajmniej w takiej postaci, w jakiej wilnianie znali ją przed wojną. Nawiązuje do tego faktu wiersz Mieczkowskiego Ważne ulice:
Ciężko jest ważnym ulicom i ich mieszkańcom - udźwignąć mają razem sławę swych patronów taka Aleja Giedymina musiała nosić piętno Lenina przedtem złowroga na niej ciążyła o Stalinie pamięć przed wojną legendą Mickiewicza pobrzmiewała i prawosławia Świętojerskim dudniła echem... [... $]^{8}$.

Dzisiaj jest to ulica Gedymina, ciągnąca się od Katedry Św. Stanisława i Władysława aż do Mostu Zwierzynieckiego. I dopiero za tym mostem, w dzielnicy Zwierzyniec, pozostał mały odcinek ulicy Mickiewicza.

Dokonaliśmy tutaj przeglądu wierszy o tej tematyce, powstałych w wyniku chodzenia śladami Wieszcza po Wilnie i oglądania różnego rodzaju spustoszeń, spowodowanych przez większe i mniejsze przewroty dziejowe.

Drugi ważny zrą̧ tekstów o tematyce Mickiewiczowskiej stanowią wiersze, odsyłające do twórczości poety, a ponieważ ta twórczość wyrastała najczęściej z przywiązania do ziemi rodzinnej, motywy przestrzenno-regionalne i literackie nakładają się często na siebie. Widoczne jest to w Piosence o Świte$z i$ Wojciecha Piotrowicza, tekście użytkowym, napisanym dla uczniowskiego zespołu artystycznego „Świtezianka”, bazującego w wileńskim Gimnazjum

\footnotetext{
7 R. Mieczkowski, Na litewskim paszporcie, Wilno 2011, s. 14.

8 Tamże, s. 13.
} 
im. Szymona Konarskiego. Już w pierwszych wersach tekstu mamy odniesienia nie tylko do ballady Świteź, lecz także do jednego z liryków lozańskich (Nad woda wielka i czysta):
Nad Świtezi wodą modrą, czystą
Bujne głowy pochyliły drzewa.
Wiatr poruszył gałęzią stulistną,
O legendzie dawnej słowik śpiewa9 ${ }^{9}$

W dalszych nawiązaniach intertekstualnych rozlegają się echa ballady Świtezianka, nazwany jest także jej twórca - „wielki Adam”.

Skoro już jesteśmy przy motywach akwatycznych, „nad Świtezi wodą”, przywołajmy też wiersz wspominanego już Romualda Mieczkowskiego Rzeka niespetnienia ze zbiorku Nikt nie woła. Znajdujemy tutaj aluzję do znanej apostrofy Niemnie, domowa rzeko moja-

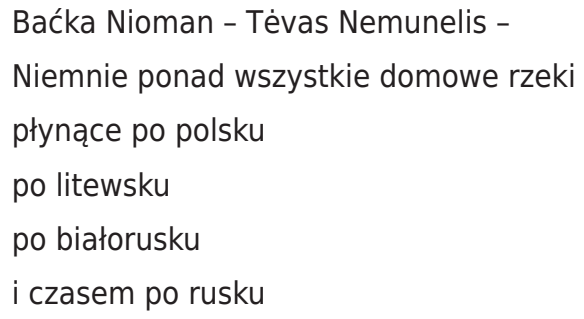

Różnojęzyczne inkrustacje dobitnie podkreślają, jak dla wielu ludzi i narodów Niemen jest „rzeką domową” i że niesie to ze sobą nie tylko pozytywne konsekwencje:

Różnie zwą ciebie z twoich brzegów różne języki słyszałeś nieraz i naraz a treść życia od wieków była jednakowa tak samo jak i rola twoja - 


\section{Obfitością wód gasić pragnienie narodów}

pośród wzajemnego niespełnienia ${ }^{10}$

Wiersz pochodzi ze zbiorku Nikt nie woła, który zawdzięcza tytuł jednemu z kluczowych utworów tomu, odsyła, oczywiście, do Stepów Akermańskich. Nostalgiczna Mickiewiczowska puenta ze znanego sonetu okazała się niezwykle przydatna także dla określenia kondycji współczesnego poety, czującego się tym razem obco także „na warszawskim bruku” (kolejna aluzja literacka). Oddalenie się od wileńskiej ojczyzny, od różnojęzycznych, ale często znajomych ludzi, nie zapewnia, o dziwo, swojskości przeniesionemu „do bezpiecznej krainy polskich szeptów" poecie:

\section{[...] Teraz kiedy jestem na warszawskim bruku gdy do ucha wyraźnie wchodzą jego słowa droga jak niegdyś wcale się nie wydłuża mogę chodzić prędko - nikt nie woła ${ }^{11}$.}

Od 2004 roku prowadzi poeta filię Polskiej Galerii Artystycznej w Warszawie, częściej przebywa więc w stolicy Polski niż w Wilnie.

Do Stepów Akermańskich nawiązuje także inny wiersz z tego samego tomi$\mathrm{ku}$ - Ostatnia niedziela sierpnia w Akermanie. Podobnie jak nieraz w wierszach „wileńskich”, dokonuje się w nim konfrontacja niegdysiejszych wrażeń Mickiewicza i doznań współczesnego poety, który odwiedził literacko uwiecznione miejsce. Przyglądanie się osławionej przestrzeni z autopsji rodzi wątpliwości:

Czy i dziś po opuszczeniu łona miłej ojczyzny rozczuliłaby Adama ta rozległa i płaska kraina pełna spalonego słońcem łanów słonecznika nieporośnięta jak wtedy ostrowami burzanu [...].

Nikła jest także pamięć o autorze sławetnych wersów:

10 R. Mieczkowski, Nikt nie woła, dz.cyt., s. 16.

11 Tamże, s. 21. 


$$
\begin{aligned}
& \text { [...] o Mickiewiczu nikt nie słyszał } \\
& \text { choć nazwisko jest jakby znane - } \\
& \text { zna je kustosz w krajoznawczym muzeum } \\
& \text { gdzie jest maleńka fotografia poety } \\
& \text { polskogo druga Aleksandra Puszkina }[\ldots]^{12} \text {. }
\end{aligned}
$$

Niszczejące pozostałości dawnej twierdzy tureckiej muszą się pogodzić z szerzeniem się współczesnej tandety: ,[...] przy Lampie Akermanu kiosk z chińszczyzną" i z innymi niepowabnymi realiami dzisiejszej rzeczywistości, które skrzętnie rejestruje pióro poety.

Nieco mniejszym wzięciem cieszą się wśród poetów wileńskich większe dzieła Mickiewicza - dramaty i poematy.

W zbiorku Władysława Ławrynowicza i Aleksandra Śnieżki $W$ stronę światta (2005) znajdujemy wiersz Grażyna. Zaistniał on jednak nie jako bezpośrednia refleksja nad poematem. Był zainspirowany, jak wszystkie teksty owego tomiku, malarstwem Ławrynowicza. Zbiorek $W$ stronę światta - jak zaznacza poeta w Przedmowie - jest odrębny o tyle, że reprodukcje obrazów malarskich nie stanowią tutaj ilustracji do wierszy, lecz odwrotnie, każdy wiersz Śnieżki jest poetycką interpretacją, dopowiedzeniem, uzupełnieniem wizji malarskiej:

\footnotetext{
Zaczekaj, Księżniczko, stój, piękna Grażyno,

Litawor z odsieczą już rusza!

Czyż Twoja to sprawa, by walczyć i ginąć?

- Do boju się rwie dzielna dusza!

Nie wejdą Krzyżacy do bram Nowogródka!

I bratnia krew ziemi nie splami!

Ojczyzna czy miłość? Pieśń piękna i krótka, Lecz wstrząsa sześcioma wiekami!13
}

Nie byłoby zatem tego „Mickiewiczowskiego” wiersza w dorobku Śnieżki, gdyby nie obraz Ławrynowicza.

12 Tamże, s. 32.

13 W. Ławrynowicz, A. Śnieżko, W stronę światta, Wydawnictwo Polskie w Wilnie 2005, s. 58. 
Natomiast w dorobku z ostatnich dekad Wojciecha Piotrowicza jest wiersz -apostrofa Konradzie, zawierający polemikę z wyrażonym w Wielkiej Improwizacji pragnieniem ,rządu dusz”:

\author{
KONRA D Z IE \\ synu natchnienia \\ Wysoko stąd \\ w echach twojego pienia \\ gwiazdy drżą \\ na ten upadek i błąd
}

Możesz duszom odmówić i s t n i e n i a

Nigdy nad nimi w z i ą ć r z ą d ${ }^{14}$.

Tenże bohater pojawia się w haiku Romualda Mieczkowskiego:
By oswoić obcych
wyobcować się wsród swoich
nie trzeba być Konradem Wallenrodem ${ }^{15}$.

Jeżeli chodzi natomiast o nawiązania do Mickiewiczowskiej „księgi ksiąg”, do Pana Tadeusza, to, jak zdarzało się też przedtem, nie sięgają one zazwyczaj dalej niż aluzje, cytaty, dotyczące Inwokacji. Pisał o tym już wcześniej, także w odniesieniu do ,poezji wileńskiej”, Wojciech Jerzy Podgórski, określając to postępowanie jako „myślenie Mickiewiczem”16.

Exemplum takiego myślenia z ostatnich dziesięcioleci stanowiłby wiersz Ireny Duchowskiej Litwo!, aluzyjny w stosunku do obu największych wieszczów:

Litwo,

tyś moim domem!

14 O. Z. Šalnienè, W. Piotrowicz, dz. cyt., s. 34.

15 R. Mieczkowski, Nikt nie woła..., s. 47.

16 W. J. Podgórski, Litwa - Polska XIX i XX wieku, Warszawa 1994, s. 147. 
Gdy cię opuszczam, tęskno mi...

W dalszym ciągu, podobnie jak w pierwszych wersach Mickiewiczowskiego arcypoematu, następuje wyliczenie niepodważalnych zalet rodzimej przestrzeni, konkretyzacja tego, do czego się tęskni:

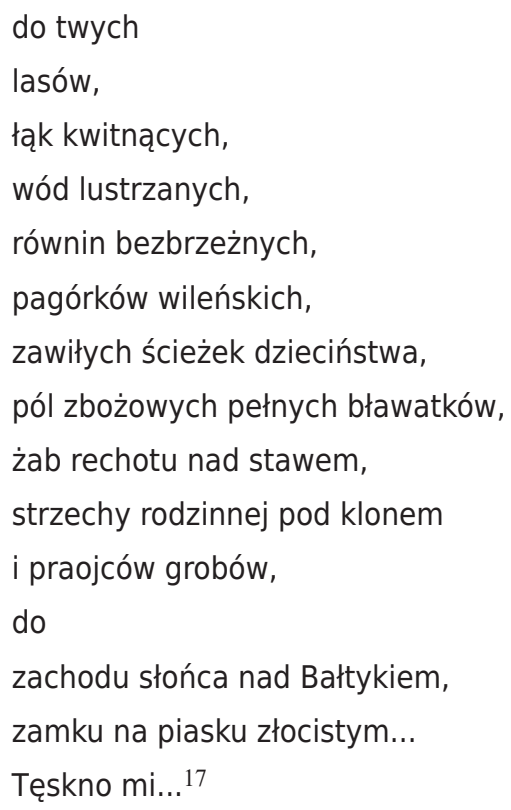

Ów tekst podany jest w zbiorku w dwóch wersjach: polskiej i litewskiej. Należy sądzić, że poetka dokonała przekładu swojego wiersza na język litewski.

Ta polsko-litewska dwójjednia nie jest dla Ireny Duchowskiej czymś przypadkowym. Jako urodzona na Wileńszczyźnie, niedaleko zresztą od Syrokomlowskiej Borejkowszczyzny, mieszkająca zaś w okolicy Kiejdan, a więc w samym „sercu Litwy”, czuje się trochę jak na wygnaniu. Bliska staje się dla niej tradycja romantyczna, o czym pisał, między innymi, Tomasz Wroczyński:

„Małą ojczyznę" autorka zawsze wpisuje w rozleglejszy, powiedzielibyśmy, patriotyczny pejzaż, charakterystyczny dla tradycji romantycznej. Ta właśnie tradycja,

17 I. Duchowska, Znad Issy, Kielce - Kiejdany 2004, s. 5. 
a zwłaszcza sugestywna legenda Litwy stworzona przez Adama Mickiewicza, wielokrotnie w jej poezji powraca. Ujawnia się nie tylko w licznych aluzjach, ale także w sposobach poetyckiego obrazowania. Litwa, Wileńszczyzna, Kiejdany wyznaczają liryczne szlaki tej twórczości ${ }^{18}$.

Bardziej odległe echo tradycji romantycznej, nawiązujące do ostrobramskiego motywu Inwokacji Mickiewiczowskiej, pobrzmiewa też w wierszu Romualda Mieczkowskiego Przed droga:
Kiedy Ciebie - Wielu Narodów Matko
czuwającą od wieków w tej samej Bramie
przychodzę pożegnać przed drogą daleką
takie mrowia ludzi masz wokół siebie
że zupełnie nie widzę oblicza Twojego -
ponad głowami świeci tylko korona [... $]^{19}$.

Przywołane dotychczas wiersze wyszły spod pióra poetów starszej i średniej generacji.

Jeszcze skromniej zarysowuje się tematyka Mickiewiczowska w utworach poetów najmłodszego pokolenia, nazywającego siebie ,,awangardą wileńską”. Prawda, niektórzy z młodych autorów przyznają się wciąż jeszcze do koligacji $\mathrm{z}$ romantyzmem.

W tym kontekście zasługiwałby na uwagę debiutancki zbiorek Tomasa Tamošiūnasa Do Krainy Wyciszenia (2012), wydany przez Muzeum Władysława Syrokomli w Borejkowszczyźnie. W nawiązującym do momentu własnych narodzin Liście z ciemności poeta sugeruje, że to sam Stwórca określił jego przynależność do romantycznych natur:

\section{[...] Dzień wybuchu \\ rozkaz z dnia 7 maja 1990 roku \\ „Otwórz oczy i słuchaj sercem“}

18 T. Wroczyński, Postowie, [w:] I. Duchowska, dz. cyt., s. 76.

19 R. Mieczkowski, Nikt nie woła..., s. 5. 


\author{
Baczność \\ podpisał \\ Ojciec - Pan Bóg ${ }^{20}$.
}

Do wiersza Pamięć wplata z kolei poeta najsłynniejszą Mickiewiczowską apostrofę, ale umieszcza ją w bardzo już niecodziennym kontekście. Rzecz dzieje się w stworzonym przez UFO muzeum, w którym można obejrzeć wynalazki przyszłości. Jednym z nich jest:

\author{
[...] żywa głowa Mickiewicza \\ z otwierającymi się ustami \\ „Litwo! Ojczyzno moja! ty jesteś jak zdrowie...“ \\ Mamo - zapytało zielone stworzenie \\ a Litwa nie wyginęła przed tysiącleciem? ${ }^{21}$
}

Patos, towarzyszący poetom starszych pokoleń przy nawiązywaniu do Inwokacji, zamienia się u młodego autora w żart, zabawę. Ten proces uwidocznił się w literaturze polskiej już w okolicach ostatniej dekady XX wieku, kiedy doszło do głosu ,pokolenie 1960".

Swoją przynależność do wciąż żywotnego w literaturze polskiej romantyzmu deklaruje także jeden z niedawnych debiutantów, Daniel Krajczyński, autor wydanego w 2015 roku zbiorku Postuchać krzyku ryb:

Nie jestem awangardowym poetą,

Czuję, jak w romantyzmie ugrzęzły me stopy $[\ldots]^{22}$.

I wreszcie w najnowszej „,antologii wierszy młodych twórców” $W$ zakolu Wilii (2016), na którą złożyły się teksty piętnastu poetów, z których większość nie ma za sobą debiutu autorskiego, natykamy się na jeden tekst, wyraziś-

20 T. Tamošiūnas, Do Krainy Wyciszenia, Muzeum Władysława Syrokomli w Borejkowszczyźnie 2012, s. 9.

21 Tamże, s. 64.

22 D. Krajczyński, Postuchać krzyku ryb, Wilno 2015, s. 49. 
cie nawiązujący do przestrzeni i twórczości Mickiewicza. Jest to wiersz Przy pomniku autorstwa Jolity Tamašiūnaite, urodzonej w 1995 roku w Wilnie.

Będąc przy wileńskim pomniku Mickiewicza zwraca się poetka do Wieszcza:

\author{
Zapal nas ogniem Dziadów \\ Myślami Pana Tadeusza \\ Nie daj zgasnąć [...].
}

Młoda poetka deklaruje jakby powrót do romantyzmu, do Mickiewicza, dostrzegając nawet jakieś paralele między niełatwą sytuacją egzystencjalną Wieszcza i współczesnego człowieka. Poleca go zatem najpewniejszej opiece, poleca Tej, której on sam najbardziej ufał:

\author{
Niech prowadzi Cię Panna \\ Co w Ostrej świeci Bramie.
}

Wiersz zamyka chyba raczej optymistyczna puenta:

\author{
Szczęście jest puste \\ Jak i ja \\ Ale razem \\ Możemy wszystko napełnić23.
}

Czy to oznacza, że młoda poetka nadal pragnie czerpać ze źródła poezji romantycznej, żywić się jej sokami? Przesłanie wiersza jakby na to wskazuje. Wskazuje też na to cały kontekst, w jakim wiersz jest umieszczony. Podobne deklaracje są jednak dzisiaj raczej sporadyczne i niezbyt głębokie.

Konkluzja byłaby zatem podobna, jak wyrażone na wstępie artykułu przypuszczenia.

W ciągu dwóch ostatnich dekad czyli pierwszych dziesięcioleci XXI wieku bardzo dotychczas żywotna u polskojęzycznych poetów wileńskich tematyka Mickiewiczowska zaczęła schodzić na dalszy plan. Coraz młodsi twórcy zdecydowanie preferują problematykę egzystencjalną.

23 W zakolu Wilii, Wilno 2016, s. 83-84. 


\section{Bibliografia}

Duchowska I., Znad Issy, Kielce-Kiejdany 2004.

Krajczyński D., Posłuchać krzyku ryb, Wilno 2015.

Ławrynowicz W., Śnieżko A., W stronę światła, Wydawnictwo Polskie w Wilnie 2005.

Mieczkowski R., Na litewskim paszporcie, Wilno 2011.

Mieczkowski R., Nikt nie woła, Wilno 2008.

Orszewska-Kursevičienè W., Ścieżka przez życie, Wydawnictwo Polskie w Wilnie 2010.

Podgórski W. J., Litwa - Polska XIX i XX wieku, Warszawa 1994.

Przenieść Wilno do serca. Portret Miasta, zebr. i oprac. R. Mieczkowski, Wilno 2009.

Šalnienè O. Z., Piotrowicz W., Spalvos ir digresijos / Barwy i dygresje, Vilnius 2002.

Tamošiūnas T., Do Krainy Wyciszenia, Muzeum Władysława Syrokomli w Borejkowszczyźnie 2012.

Turkiewicz H., Motywy Mickiewiczowskie we współczesnej polskiej poezji Litwy, [w:] Wilno i Ziemia Mickiewiczowskiej pamięci, red. E. Feliksiak, Białystok 2000.

Wroczyński T., Posłowie [w:] I. Duchowska, Znad Issy, Kielce-Kiejdany 2004, s. 76-77.

W zakolu Wilii. Antologia wierszy młodych twórców, wybór i redakcja J. Szostakowski, Wilno 2016. 